\title{
Safe-Deposit Box Using Fingerprint and Blynk
}

\author{
Yulianto $^{1 *}$, Budi Juarto ${ }^{2}$, Ika Dyah Agustia Rachmawati ${ }^{3}$, Risma Yulistiani ${ }^{4}$ \\ ${ }^{1,2,3,4}$ Computer Science Department, BINUS Graduate Program - Master of Computer Science, \\ Bina Nusantara University, \\ Jakarta, Indonesia 11480 \\ yulianto003@binus.ac.id; budi.juarto@binus.ac.id; ika.rachmawati@binus.ac.id; \\ risma.yulistiani@binus.ac.id \\ *Correspondence: yulianto003@binus.ac.id
}

\begin{abstract}
The criminal act of robbery really makes people nervous, especially in urban areas. There are many ways that can be done to avoid robbery at home and office, such as increasing the security system in the house to protect valuables. Safe-deposit boxes are items that are used to store valuables. Safe-deposit box is used to prevent against theft who want to take valuable things. To increase security, technology has begun to develop for security in various ways, such as fingerprints, passwords, and buzzers. This research will focus on a safe security system using a fingerprint that is connected to the internet with the Blynk application so that the user will get a safe notification when the servo condition is open or closed. The fingerprint sensor is an access to open doors, the Arduino Uno microcontroller is a storage for command logic on the system, the stepper motor acts as an activator for opening and closing servo and the Esp8266 module as a Wi-Fi module that connects equipment components using the internet network with the Blynk application which is used as distance control and notification of incoming access to homes with the concept of Internet of Things (IoT).
\end{abstract}

Keywords: Arduino Uno; Fingerprint; ESP8266; Blynk; IoT.

\section{INTRODUCTION}

Theft is one of the most common crimes in Jakarta. In 2020 , there were 5,876 cases during the 24th week of the PSBB period in Jakarta (Saputra \& Asep, 2020). The increase in theft cases has occurred in shopping center such as minimarket (Wijayaatmaja \& Yakub, 2020). So, it needs better security (Wang et al., 2021) (Hamas et al., 2021), especially to protect valuables such as money. The application of electronic technology is one solution to be applied such as a safe-deposit box security system using a fingerprint sensor, which is connected to the internet via a smartphone.

Safe-deposit box is a container for storing someone's valuables. In use, it is usually done by individuals and several people at once. The use of safe-deposit boxes itself aims to secure valuables from criminal acts of theft of valuables. To increase the security of the safe, you can apply information-based security systems such as the Internet of Things (IoT) and fingerprint. We prefer to choose a fingerprint sensor to access the safe deposit box inspired by the disadvantage of the mechanical lock system where the user could misplace, lose, or leave her key at another place (Al-Shareefi et al., 2021) (Mispan et al., 2022). The use of biometric fingerprint can increase the security of a safedeposit box because it can only be accessed by people who enrolled on the fingerprint. In addition, the safe-deposit box also uses the Blynk application to open and close the safe so that the safe can be integrated with IOT also has another way to open the safe if the fingerprint does not work.

\subsection{Literature Review}

To increase the security system on vehicles, the Fingerprint for lock and unlock system has been adopted by (Alsayaydeh et al., 2019) to implement on the vehicles door prototype. The microcontroller has used Arduino Uno. The highest score value got 222.6 from a maximum of 255 . Lock system based Short Message Service (SMS) gateway (Hamas et al., 2021), unlocked by phone (Perng \& Hsieh, 2019), and RFID with access to unlock using Electronic Kartu Tanda Penduduk (E-KTP) (Najib et al., 2021) has disadvantage where if the user forgets left their phone and E-KTP, they can't access to unlock and lock. The research conducted by (Hoque \& Davidson, 2019) just discussed the reed sensor that can detect if the door environment opens and does not discuss how to give the lock system yet. 


\section{METHODS}

There are three stages of system design in this study. The first stage system design scheme of safe-deposit box is presented in Figure 1.

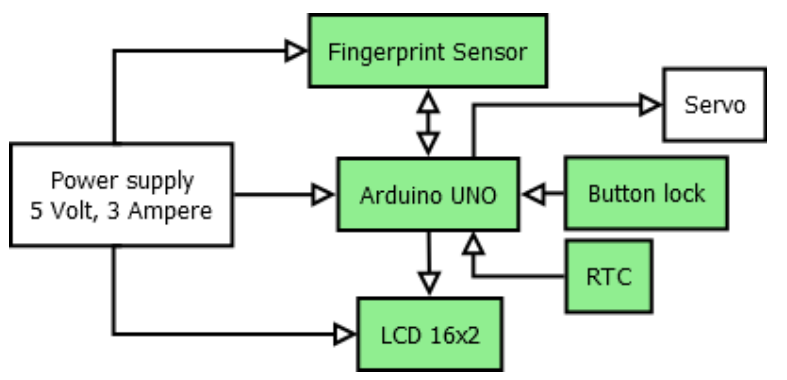

Figure 1. Block diagram of stage I system design

The block diagram in Figure 1 can used to lock and unlock the safe deposit box via offline. In prototype manufacturing, the components used are as follows:

\section{Arduino UNO}

Arduino UNO is used as a microcontroller that controls the course of the program (Lee et al., 2021).

2. Fingerprint sensor

Fingerprint scanner is a sensor that will be used as a biometric recognition sensor (Priesnitz et al., 2021) in the form of fingerprint from the unlock.

3. RTC

RTC (Real Time Clock) is used to record the unlock time using fingerprint in real time (Nguyen et al., 2021).

4. LCD $16 \times 2$

LCD 16x2 (Liquid Crystal Display) is used to display information from the program (Hakim \& Manurung, 2020), including display lock status, unlock information using fingerprint, unlock time and information when box is opened through by Blynk application.

5. Servo

The lock and unlock mechanism on the safe depositbox will be controlled using a lever's servo motor.

6. Button

Button on prototype serves as lock button, to lock safe deposit-box.

7. NodeMCU ESP8266

NodeMCU ESP8266 is used as a replacement for the Wi-Fi module that connects the tool with the internet network, so that it can be connected to applications on the Blynk platform (Setyawan et al., 2020).

The second stage system design diagram, namely the IoT design based on ESP8266 and Blynk Cloud Server, is presented in Figure 3.

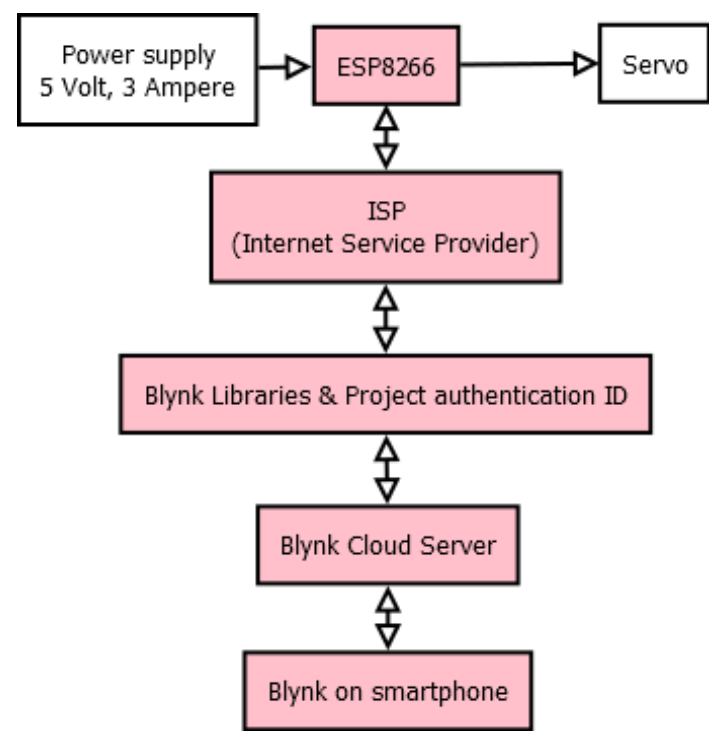

Figure 2. Block diagram of stage II system design of Node

MCU that can be controlled by Smartphone via Blynk. In Figure 2, describe how the workflow of ESP8266, servo motors and resources. The diagram illustrates the process of connecting the tool with the internet network until it reaches the stage of controlling the key through the Blynk application. The tool will connect to the internet network via WIFI connection ESP8266 with Internet Service Provider (ISP), then after connecting with the internet, the program on the Blynk platform will be synchronized using project authentication ID. Once the authentication process is complete, the program will be forwarded to Blynk Server Cloud, finally the tool can be controlled using Blynk application on smartphone

The third stage system design diagram is carried out by combining the two previous stages to produce an IoT design for a safe-deposit box security system based on Arduino Uno, ESP8266, fingerprint sensor and Blynk application on smartphones as shown in Figure. 3.

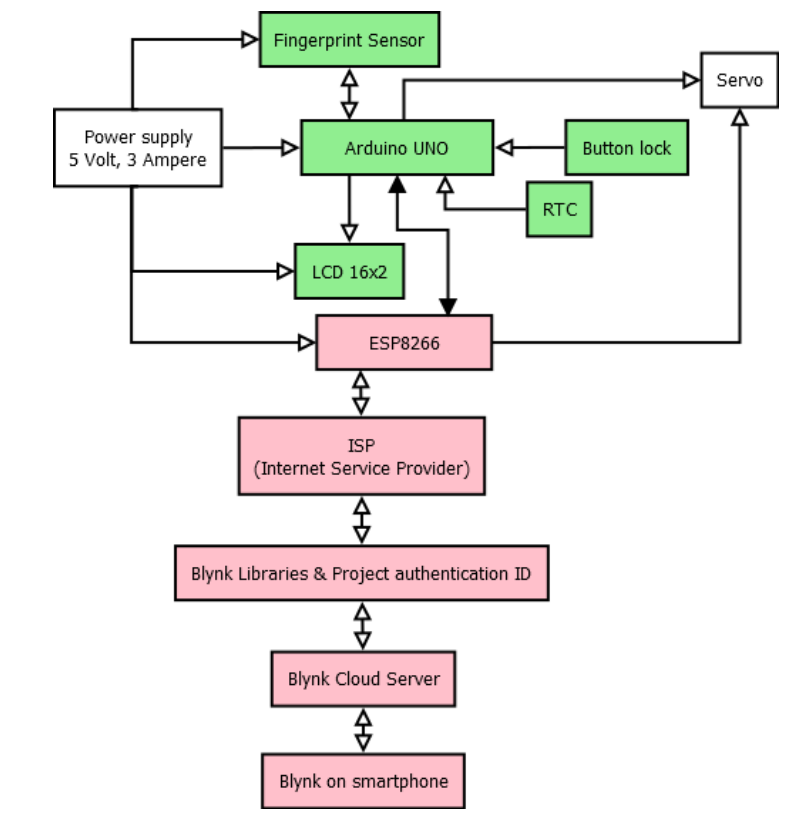

Figure 3. Block diagram of stage III design combination between Arduino and Node MCU controller. 
In Figure 3, the diagram illustrates the workflow of the tool as a whole, at this stage the system has been integrated with the Internet. The safe deposit-box key will be controlled via the Blynk application and the button on the tool, while for the main unlocking it will use a fingerprint sensor, users who can unlock via fingerprint are only users whose fingerprints have been recognized by the system, while for an alternative to unlocking, users can use the unlock button on the Blynk app. Every status information on the prototype will be displayed on the LCD, including the locked status, who is the unlocker and the unlocking time.

\section{RESULTS AND DISCUSSION}

The Result of the experiment shows that safe deposit box can lock and unlock the box properly, to make our system works properly, first we must takes enroll the biometric data from the finger of user that has a right access to open the box. The type of finger scan sensor that our used is FPM10A. The microcontroller that was our used based Arduino Uno. The reasons why in our experiment used Arduino because we used to many sensor and output device module that used port serial and port I2C such as LCD16 2 , RTC DS1307, Servo with single wire data, and finger scan module. All those devices need more port I/O. Then to make the box could be accessed through internet networks, we added the Node MCU ESP8266 module and connected it to the Arduino through a port serial. The broker cloud service provider that our used to get accessed to the Box is Blynk. The result of the experiment we could open the Box by person that have been took of finger enroll biometric process before, and an emergency condition we could open the Box through Android smart phone devices. The results of the safe deposit box are shown in Figures 4 and 5. Figure 4 shows the front view of safe deposit box which show the person who scan the fingerprint scanner and the time of the person who scan the box and record it. Figure 5 shows the installation of safe deposit box which the mechanism of lock and unlock is done by servo.

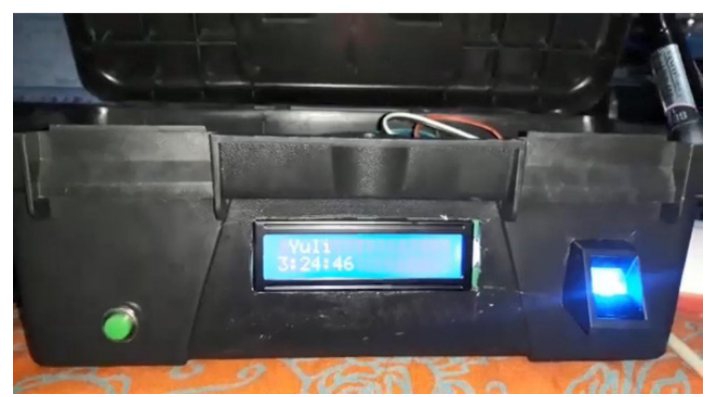

Figure 4. Safe Deposit Box Front View

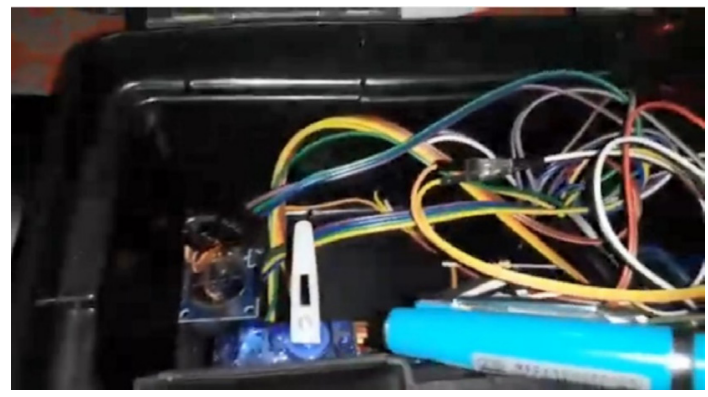

Figure 5. Safe Deposit Box Installation In Inside View
In this research, we conducted an experiment with 10 people to measure the process time of opening and closing safe deposit boxes. Measurements were also carried out in the fingerprint registration process of 10 people. Table 1 shows 10 times for each person in the activity of opening the safe deposit box and Table 2 shows 10 times for each person in the fingerprint registration activity.

\begin{tabular}{|c|c|c|}
\hline No & Person & Time \\
\hline 1. & $\mathrm{~A}$ & 1.42 \\
\hline 2. & $\mathrm{~B}$ & 1.63 \\
\hline 3. & $\mathrm{C}$ & 1.12 \\
\hline 4. & $\mathrm{D}$ & 1.64 \\
\hline 5. & $\mathrm{E}$ & 1.5 \\
\hline 6. & $\mathrm{~F}$ & 1.34 \\
\hline 7. & G & 1.72 \\
\hline 8. & $\mathrm{H}$ & 1.2 \\
\hline 9. & $\mathrm{I}$ & 1.94 \\
\hline 10. & $\mathrm{~J}$ & 1.71 \\
\hline \multicolumn{3}{|c|}{ Table 2 Fingerprint Registration Tim } \\
\hline No & Person & Time \\
\hline 1. & A & 5.77 \\
\hline 2. & $\mathrm{~B}$ & 5.38 \\
\hline 3. & $\mathrm{C}$ & 5.66 \\
\hline 4. & $\mathrm{D}$ & 5.05 \\
\hline 5. & $\mathrm{E}$ & 5.16 \\
\hline 6. & $\mathrm{~F}$ & 5.58 \\
\hline 7. & G & 5.71 \\
\hline 8. & $\mathrm{H}$ & 5.3 \\
\hline 9. & I & 5.97 \\
\hline 10. & $\mathrm{~J}$ & 5.16 \\
\hline
\end{tabular}

\section{CONCLUSION}

After testing and analysis, the following conclusions can be obtained, such as:

1. From the results of the fingerprint sensor testing, it takes around 1 second to open safe deposit box, while registering fingerprints until they are stored takes 5 seconds.

2. Testing servo control using the blynk application on a smartphone using the internet network with the help of the ESP8266 module installed, can run well as long as it is connected to an internet connection and with a good and stable internet network ping.

3. From the test results, the whole system works well, if access is made using the fingerprint sensor with the stored fingerprints, the LCD display will display the info of the person done the scanning and the time of scanning, and if access is done with fingerprints that cannot be done then can be opened with the blynk application. 


\section{REFERENCES}

Alsayaydeh, J. A. J., Khang, A. W. Y., Indra, W. A., Pusppanathan, J. B., Shkarupylo, V., Zakir Hossain, A. K. M., \& Saravanan, S. (2019). Development of vehicle door security using smart tag and fingerprint system. International Journal of Engineering and Advanced Technology, 9(1), 31083114. www.scopus.com

Al-Shareefi, N. A., Abbas, S. A., Alkhazraji, M. S., \& Sakran, A. A. (2021). Towards secure smart cities: design and implementation of smart home digital communication system. Indonesian Journal of Electrical Engineering and Computer Science, 21(1), 271-277.

Hakim, L., \& Manurung, B. (2020). Design and analytical simulation of heart rate measurement and human body temperature with linear regression approach. AIP Conference Proceedings, 2221(1), 100002. https://doi.org/10.1063/5.0003189

Hamas, A., Muneer, A., \& Fati, S. M. (2021). Smart security door system using SMS based energy harvest. International Journal of Electrical \& Computer Engineering (2088-8708), 11(4).

Hoque, M. A., \& Davidson, C. (2019). Design and Implementation of an IoT-Based Smart Home Security System. International Journal of Networked and Distributed Computing, 7(2), 85-92. https://doi. org/10.2991/ijndc.k.190326.004

Lee, J., Kim, T. W., Lee, C., \& Koo, C. (2021). A scalable platform for investigating the space-specific features of the temporal energy usage pattern and saving potential with real-time bigdata. Journal of Cleaner Production, 314, 128028. https://doi.org/https://doi.org/10.1016/j.jclepro. 2021.128028

Mispan, M. S., Jidin, A. Z., Kamaruddin, M. R., \& Nasir, H. M. (2022). Lightweight hardware fingerprinting solution using inherent memory in off-the-shelf commodity devices. Indonesian Journal of Electrical Engineering and Computer Science, 25(1), 105-112. www.scopus.com

Najib, A., Munadi, R., \& Karna, N. B. A. (2021). Security system with RFID control using E-KTP and internet of things. Bulletin of Electrical Engineering and Informatics, 10(3), 1436-1445. https:// doi.org/10.11591/eei.v10i3.2834

Nguyen, B., Goto, B., Selker, J. S., \& Udell, C. (2021). Hypnos board: A low-cost all-in-one solution for environment sensor power management, data storage, and task scheduling. HardwareX, 10, e00213. https://doi.org/10.1016/j.ohx.2021. e00213

Perng, J.-W., \& Hsieh, T.-L. (2019). An Electromagnetic Lock Actuated by a Mobile Phone Equipped with a Self-Made Laser Pointer. Electronics, 8(12). https://doi.org/10.3390/electronics8121524

Priesnitz, J., Rathgeb, C., Buchmann, N., Busch, C., \& Margraf, M. (2021). An overview of touchless 2D fingerprint recognition. EURASIP Journal on Image and Video Processing, 2021(1), 8. https:// doi.org/10.1186/s13640-021-00548-4

Setyawan, F. X. A., Sulistiyanti, S. R., Purwiyanti, S., Fitriawan, H., \& Adnan, A. R. (2020). Monitoring and control system with a client-server model based on Internet Of Things (IOT). IIUM Engineering Journal, 22(1), 93-102. https://doi. org/10.31436/iiumej.v22i1.1596

Wang, R.-J., Lai, S.-C., Jhuang, J.-Y., Ho, M.-C., \& Shiau, Y.-C. (2021). Development of Smart Home Gesture-based Control System. Sensors and Materials, 33(10), 3459-3471.

Saputra, Asep Adi. (2020). Polri: Kejahatan Meningkat Selama PSBB, Pencurian Mendominasi. Retrieved 20 October, 2020, from CNN Indonesia: https://www.cnnindonesia.com/ nasional/20200420185641-12-495403/polri-kejahatan-meningkat-selama-psbb-pencurian-mendominasi.

Wijayaatmaja, Yakub Pryatama. (2020). Polri Sebut Angka Kriminalitas Naik 38,45\%. Retrieved 20 October, 2020, from CNN Indonesia: https://mediaindonesia.com/read/detail/321027-polri-sebut-angka-kriminalitas-naik-3845 